\title{
Public policy reform and police prevention practice: a journey upstream?
}

\author{
BLAND, N., CALDER, A., FYFE, N.R., ANDERSON, S., MITCHELL, J. and \\ REID, $S$.
} Licence v3.0 (http://www.nationalarchives.gov.uk/doc/open-government-licence/version/3/). 
Article

\title{
Public Policy Reform and Police Prevention Practice: A Journey Upstream?
}

\author{
Nick Bland (D) *, Amy Calder**, Nicholas R. Fyfe***, Simon Anderson****, \\ James Mitchell $* * * * *$ and Susan Reid******
}

\begin{abstract}
This article contributes to a growing body of research on the police reforms in Scotland. It examines the particular place given to prevention in public policy and its impact on police practice. We show how public policy reconfigured the place and purpose of prevention for the police, with a focus on safety, wellbeing, and the prevention of harm. The research draws on qualitative data collected in four areas as part of a 4-year evaluation of the police reforms. We refine a public health typology of prevention and operationalize it empirically for the first time to analyse cases of innovative practice. We distinguish a pattern of prevention practice heavily weighted towards secondary prevention, focused predominantly on issues of crime and disorder. In fewer cases, the police applied primary and tertiary prevention, with a focus on vulnerability and harm. Looking in detail at two cases, we illustrate the importance of collaboration for the police, which created opportunities and brought additional resources and expertise to support new prevention approaches which had a significant impact on effectiveness. The police realized collaborative advantage through common aims, trust-building, and leadership. We do not suggest this demonstrates a transformation in police prevention; it illustrates successful police innovation, and identifies the potential to go further. The implications for policy and practice are to recognize the value to the police of investing in new partnerships. They create opportunities for the police to collaborate, innovate, and focus more sharply on the prevention of harm.
\end{abstract}

\section{Introduction}

The major policy reform that established a single police force in Scotland in 2013 has been subject of a broad range of scholarly study. This includes assessment of the implications of the new legislative framework (Scott, 2012), the new form of national governance (Malik, 2017), local governance arrangements (Henry et al., 2019), and the impact of centralization on local delivery (Fyfe et al., 2018). Comparisons with the police reform initiatives of other countries across Europe have identified similar challenges and responses (Fyfe

${ }^{*}$ Nick Bland, School of Applied Sciences, Edinburgh Napier University, Edinburgh, UK. E-mail: nrcbland@gmail.com

${ }^{*}$ Amy Calder, School of Social Sciences, Scottish Institute for Policing Research, University of Dundee, Dundee, UK

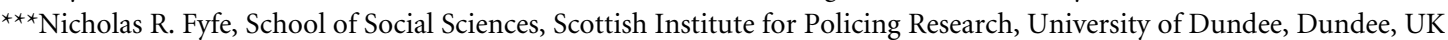

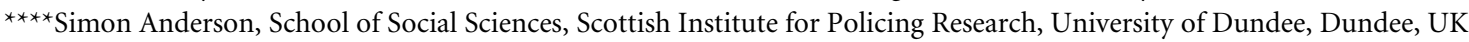

*****James Mitchell, School of Social and Political Sciences, University of Edinburgh, Edinburgh, UK

$* * * * * *$ Susan Reid, ScotCen Social Research, Edinburgh, UK

Advance Access publication: 22 February 2021

Policing, Volume 15, Number 3, pp. 1882-1893

doi:10.1093/police/paab008

(c) Crown copyright 2021.

This article contains public sector information licensed under the Open Government Licence v3.0 (http://www.nationalarchives.gov.uk/doc/open-government-licence/version/3/) 
et al., 2013). A gap in this growing body of knowledge is the particular place given to prevention in the Scottish police reforms and its impact on police practice. ${ }^{1}$

The police have, of course, long been identified with prevention activity, but this focused narrowly on preventing crime (Gilling, 2019). This has been described as a 'technical' focus, often identified with situational crime prevention (Clarke, 1980). Moves to a broader concern with preventing crime and disorder, and the associated focus on community safety, saw a widening of responsibility to include non-policing actors (Tilley and Sidebottom, 2017). However, we will show how the reforms in Scotland repositioned the police in a broader public policy prevention agenda, and which distinguished it from how policy developed in neighbouring England and Wales (Fyfe and Henry, 2012). This change was expressed by the police at a strategic level in a concern to focus on 'vulnerability' and to prevent 'harm' (Police Scotland and Scottish Police Authority, 2017).

Drawing from research conducted in 2017 as part of a 4-year evaluation of the police reforms in Scotland (SIPR, What Works Scotland and Scotcen, 2018), we explore whether and how the policy of prevention is reflected in police prevention practice. We refine a public health typology which differentiates primary, secondary, and tertiary prevention (Coote, 2012), and operationalize it empirically. This enables us to distinguish the pattern of police preventive practice found in four local areas. To place this in context, we examine the impact of the structural reform of the police service, and the challenges experienced by officers involved in prevention activity. We focus on two specific cases to illustrate the importance of collaboration in new partnerships for the police, which created opportunities and brought additional resources to support new prevention approaches. To conclude, we consider the implications of the pattern of preventive practice our research finds: a heavy focus on secondary prevention and scope for further expansion into primary and tertiary approaches. We examine whether this can be described as a transformation in police prevention and consider what the police, as the archetypal reactive emergency service (Bittner, 1990), can reasonably be expected to contribute to prevention policy in Scotland.

\section{Context: public policy and prevention in Scotland}

We begin by describing a number of public policy developments in Scotland between 2011 and 2015 which shaped the landscape in which the new Scottish police service developed, and we show how this reconfigured the place and purpose of prevention for the police. An emphasis on prevention stems from the 2011 Commission on the Future Delivery of Public Services, established by the Scottish Government. The Commission report argued for tackling what it described as 'failure demand' (see Seddon, 2009) through a 'shift to prevention' and a focus on working increasingly in partnership. The Commission identified prevention as central to a successful policy response to the contemporary situation in Scotland. It summarized the challenges the country faced as: stubborn and persistent social and economic inequalities, increasing demand falling on public services, and a continuing reduction in real-terms funding (Commission on the Future Delivery of Public Services, 2011). Such issues, or 'wicked problems', are socially complex, where solutions are not in the capacity of individual public services working in a 'silo' but rather require responses that span the fragmented system of public service delivery (Rittel and Webber, 1973). As such, the challenges they present are faced equally by the police as by their public service partners.

\footnotetext{
${ }^{1}$ The Prevention First programme in New Zealand is another notable example where preventive activity was given a higher profile as part of police reforms. The focus of the programme was described as 'taking every opportunity to prevent harm' (New Zealand Police, 2017).
} 
The creation of a single police service in Scotland (now named in practice as Police Scotland) was founded on the Police and Fire Reform (Scotland) Act 2012. Section 32 of that act established for the first time in Scotland a statutory definition of the purpose of policing, which was to 'improve safety and wellbeing'. The police were required to pursue that purpose in ways that 'promote measures to prevent crime, harm, and disorder'.

There are a number of specific elements important to note in this legislative change. First, the purpose of the police is defined positively as making improvements to specified social outcomes (i.e. increasing social goods), rather than defined negatively in terms of the conventional police outputs of crime reduction and detection (i.e. reducing social ills). This can be seen to be reflective of a broader 'outcome-focus' promoted by the Scottish Government since the Scottish National Party came into power in 2007 (Cairney et al., 2016).

Second, the legislation identifies the police with improving the specific outcomes of 'safety and wellbeing'. It repositions the police as contributing to these wider social outcomes which are shared with other public services, in contrast to their traditional law and order remit, for which they were held primarily responsible. Third, the importance of prevention is re-emphasized, and also very significantly the focus of police preventive activity is extended by the inclusion of an explicit reference to preventing 'harm'. Together, this represents a significant expansion of focus for the police from the prevention of crime and disorder.

The significance of this change is further reinforced when it is compared with the prior legislative foundation for policing in Scotland-the Police (Scotland) Act 1967-in which there is no equivalent definition of an overarching policing purpose. Section 17 of the 1967 legislation, in contrast, defines only duties for individual police constables: 'to guard, patrol and watch so as to prevent the commission of offences; to preserve order, and to protect life and property'. This narrow description of policing in terms of the activities and outputs of individual police officers places the 2012 legislative description of policing in sharp relief.

Further legislative change came with the Community Empowerment (Scotland) Act 2015 which sought to strengthen arrangements for Community Planning Partnerships, established in each of the 32 local authority areas in Scotland. For the first time, the 2015 legislation placed statutory responsibility on the police, as a named local community planning partner, to reduce inequalities of outcome in that area, collaborating with the local authority, fire service, health board, and others.

Together, these public policy and legislative developments reposition the police as contributors to a wider cross-public service agenda promoted by the Scottish Government of tackling inequalities, with an emphasis on a preventive approach (Scottish Government, 2011). This policy context was reflected in the 10-year strategy 'Policing 2026 ' which identified the centrality of prevention for Police Scotland directed at 'inequality and enduring problems facing communities' (Police Scotland and Scottish Police Authority, 2017, p. 15). It further emphasized that the police needed 'to be in a position where our resources can focus preventative support on high-impact issues like vulnerability and mental health, domestic abuse and drug/alcohol abuse' (ibid, p. 29). The police identify in this way their strategic focus on harm prevention. In the sections that follow we explore whether and how this national policy context is reflected in actual police preventive practice at the local level.

\section{Methods}

This article draws on research which forms part of an independent 4-year evaluation of police reform in Scotland (SIPR, Scotcen and What Works Scotland, 2016, 2017; SIPR, What Works Scotland 
and Scotcen 2018) commissioned by the Scottish Government. Specifically, it presents data collected in 2017 into the practices of prevention and partnership collaboration. Fieldwork was conducted in four local areas: two areas selected in an earlier phase of the evaluation, and revisited for this research, and two new areas identified as sites of innovative practice. The choice of the two areas was guided by information we collected from Police Scotland, the Scottish Police Authority, and Her Majesty's Inspectorate of Constabulary in Scotland about examples of innovation in partnership and prevention activity. The information provided was complemented by our own research, which identified initiatives through news articles and public awards given to police prevention activities for public service excellence. This produced a 'longlist' of innovative examples across the country, from which the two areas were selected. The case study areas have been anonymized and will hereby referred to as

- Area A-urban area

- Area B-remote rural area

- Area C-rural area

- Area D-large urban area

In each of the four areas, qualitative interviews and focus groups were carried out between May and August 2017. Interviewees were also asked to provide any evidence, including reports and evaluations, of partnership working and prevention. This provided an opportunity to triangulate the evidence provided with the experiences and perspectives of the interviewees. The evidence provided was specific to the areas and as such the documents are not referenced in this article, to protect anonymity.

In total, interviews were conducted with 40 police officers and partners. All were selected because they held a particular remit for partnership and prevention work. The majority worked at a strategic level including in local partnerships. Interviews were conducted with the following: police officers-from constable to chief superintendent $(n=12)$; and partners-from the fire and rescue service, NHS, council, social work, housing, third sector $(n=28)$. A focus group was also conducted in each of the four areas; this brought together police officers and partners involved in a specific initiative in each area that we identified from the interviews as worthy of further study $(n=4)$.

The majority of the interviews took place face to face but a small number were conducted via telephone. The focus groups were facilitated by one or two researchers. With the consent of participants, the interviews and focus groups were digitally recorded, transcribed verbatim, and analysed thematically. Interview extracts in this article have been anonymized, and are identified according to an alpha-numerical code.

\section{A typology of prevention}

The importance placed on preventive public policy and its 'at face-value' advantages can be seen across most western countries over the past few decades (Gough, 2015; Cairney et al., 2016). The notion of prevention described in government policy documents tends to be vague and ambiguous; it expresses more a normative ideal than describes a set of concrete practices (Cairney et al., 2016, p. 342). Equally, there is a recognition that prevention is difficult to define, with an understanding that 'there is no single formula for preventing harm' (Coote, 2012, p. 11).

To better define and understand prevention, a public health typology distinguishes between primary, secondary, and tertiary prevention; also described as upstream, midstream, and downstream prevention (Coote, 2012). The three categories of prevention are described as follows:

Primary (upstream) prevention aims to prevent harm before it occurs;

Secondary (midstream) prevention aims to reduce the impact of harm that has already occurred by 
introducing initiatives to prevent it reoccurring;

Tertiary (downstream) prevention aims to soften the impact of ongoing harm. (Coote, 2012)

This typology has also been applied to understandings of crime prevention. Brantingham and Faust (1976) first applied it as a means for better conceptualizing crime prevention and to overcome what they saw as the 'definitional ambiguity and theoretical contradiction' (Ibid, p. 284) of discussions of prevention in criminology. Their approach was later refined by van Dijk and de Waard (1991), who added the insights of routine-activity theory (Cohen and Felson, 1979). The typology has received some more recent attention in conceptual discussions of crime prevention, without further elaboration or development (e.g. Kautt and Pease, 2012; Gilling, 2019).

In the following, we operationalize this typology for the first time empirically, to analyse the prevention activity of the police in the four case study areas. In doing so, we also go further to refine the typology by breaking it down along three dimensions: the focus of prevention activity, the preventive practices employed, and the partnerships in which the police collaborate. A total of 19 cases of innovative prevention activity were identified in the interviews with police and partners in the four study areas. An analysis of the cases is set out in Table 1, categorized according to the public health typology, and along the three dimensions of preventive focus, practices, and partners.

\section{Patterns of prevention}

Our analysis in Table 1 identifies patterns of prevention practice by the police. In the majority of cases (14/19), the police applied secondary prevention approaches. The focus of these midstream interventions tended to be on crime and disorder prevention; the majority aimed at anti-social behaviour and community safety, often related to young people. In those instances, the practices the police used most were targeted warnings, diversionary activity, and environmental improvements. Commonly, partnerships were with the fire service and officers from different council services such as community wardens and housing. A notable exception to this picture is an example of harm prevention focused on suicide; in that instance, the police worked with partners in the NHS and the fire service to learn lessons from past incidents of suicide.

Our analysis identifies four cases where the police applied primary prevention approaches. The focus of all of these upstream interventions was on safety: one case specifically on road safety, another on water safety, and the other two on broader community safety. The practice of the police in each case was to deliver educational input in a school, college, or other educational setting, aimed at children and young people. The police did this in collaboration with a range of partners including the fire and ambulance services, schools, and colleges.

We identify only one example of a tertiary prevention approach. The police used a downstream intervention to improve how they responded to emergency incidents of mental health distress in vulnerable adults, with a focus on their wellbeing. It involved them collaborating closely with parts of the NHS they had not done so previously: mental health services and accident and emergency. It required emergency response officers to learn new practices and to work routinely for the first time with mental health workers. This case is considered in further detail later in the article.

We have used this typology to examine empirically the concrete practices of prevention by the police. First, and not simplistically, it shows that not all preventive activity is the same. We are able to differentiate types of prevention activity by the police. Second, it means we identify the different targets for police prevention, different kinds of preventive 'problem'. Third, it shows that preventive activity produces different kinds of impact. 
Table 1: Primary, secondary, and tertiary prevention practices

\begin{tabular}{|c|c|c|}
\hline \multicolumn{3}{|l|}{ Primary prevention } \\
\hline Preventive focus & Prevention practices & Partnerships \\
\hline $\begin{array}{l}\text { Water safety with school } \\
\text { children }\end{array}$ & $\begin{array}{l}\text { Educational input to children in a } \\
\text { school setting about the dangers of } \\
\text { open water }\end{array}$ & $\begin{array}{l}\text { Police, drugs and alcohol teams, RNLI, } \\
\text { British Gas }\end{array}$ \\
\hline $\begin{array}{l}\text { Road safety with school } \\
\text { children }\end{array}$ & $\begin{array}{l}\text { Early intervention, experiential learning } \\
\text { approach for pre-driver age young } \\
\text { people in a non-educational setting }\end{array}$ & Police, fire, ambulance, local businesses \\
\hline $\begin{array}{l}\text { Community safety with vul- } \\
\text { nerable groups }\end{array}$ & $\begin{array}{l}\text { Educational inputs to schools and vul- } \\
\text { nerable groups about community } \\
\text { safety }\end{array}$ & $\begin{array}{l}\text { Police, council, and community } \\
\text { wardens }\end{array}$ \\
\hline $\begin{array}{l}\text { Community safety with young } \\
\text { people }\end{array}$ & $\begin{array}{l}\text { Campus officers delivering educational } \\
\text { inputs and presence in educational } \\
\text { and further education setting }\end{array}$ & Police, schools and colleges \\
\hline \multicolumn{3}{|l|}{ Secondary prevention } \\
\hline Preventive focus & Prevention practices & Partnerships \\
\hline $\begin{array}{l}\text { Fire related anti-social } \\
\text { behaviour }\end{array}$ & $\begin{array}{l}\text { Environmental improvements to pre- } \\
\text { vent young people setting fires }\end{array}$ & $\begin{array}{l}\text { Police, fire, environmental services, } \\
\text { community wardens, and local } \\
\text { schools }\end{array}$ \\
\hline $\begin{array}{l}\text { Young people at risk of } \\
\text { offending }\end{array}$ & $\begin{array}{l}\text { Residential education encouraging self- } \\
\text { discipline in young people }\end{array}$ & Police and Prince's Trust \\
\hline Suicide prevention & $\begin{array}{l}\text { Multi-agency approach to learn lessons } \\
\text { after suicide to prevent future deaths }\end{array}$ & Police, fire, and NHS \\
\hline Community safety & $\begin{array}{l}\text { Long-term information sharing to im- } \\
\text { prove outcomes for community } \\
\text { members }\end{array}$ & $\begin{array}{l}\text { Police, fire, council, anti-social behav- } \\
\text { iour team, housing, social work, } \\
\text { community wardens }\end{array}$ \\
\hline Community safety & $\begin{array}{l}\text { Long-term multi-agency approach to } \\
\text { community safety }\end{array}$ & Police, fire, schools, council \\
\hline $\begin{array}{l}\text { Anti-social behaviour with } \\
\text { young people }\end{array}$ & $\begin{array}{l}\text { Contractual agreement with young } \\
\text { people to prevent continuing anti-so- } \\
\text { cial behaviour }\end{array}$ & Police and council \\
\hline $\begin{array}{l}\text { Anti-social behaviour with } \\
\text { young people }\end{array}$ & Diversionary activities for young people & $\begin{array}{l}\text { Police, youth workers, college, fast } \\
\text { food chain }\end{array}$ \\
\hline Dangerous driving & Targeted warnings about speeding & Police and council \\
\hline Drug misuse & $\begin{array}{l}\text { Environmental improvements to pre- } \\
\text { vent drug misuse in cemeteries }\end{array}$ & Police, council and crematorium \\
\hline $\begin{array}{l}\text { Young people at risk of } \\
\text { offending }\end{array}$ & $\begin{array}{l}\text { Educational programme with young } \\
\text { people at risk of offending }\end{array}$ & Police, fire, army \\
\hline Anti-social behaviour & $\begin{array}{l}\text { Targeted warnings about night-time } \\
\text { noise }\end{array}$ & Police, fire, council \\
\hline Rural crime & Educational, security advice to farmers & Police and fire \\
\hline Anti-social behaviour & $\begin{array}{l}\text { Targeted warnings about anti-social be- } \\
\text { haviour in town centres }\end{array}$ & $\begin{array}{l}\text { Police, elected members, community } \\
\text { wardens }\end{array}$ \\
\hline Anti-social behaviour & $\begin{array}{l}\text { Prevention First-focused anti-social } \\
\text { behaviour prevention }\end{array}$ & Police, housing, community wardens \\
\hline \multicolumn{3}{|l|}{ Tertiary prevention } \\
\hline Preventive focus & Prevention practices & Partnerships \\
\hline $\begin{array}{l}\text { Vulnerable adults experiencing } \\
\text { mental health distress }\end{array}$ & $\begin{array}{l}\text { Long-term multi-agency partnership } \\
\text { supporting incident-based response } \\
\text { by emergency response officers }\end{array}$ & $\begin{array}{l}\text { Police, council, NHS mental health, and } \\
\text { A\&E }\end{array}$ \\
\hline
\end{tabular}


Lastly, we are able to distinguish patterns of prevention the police are involved in, which show the weight of their effort is on midstream interventions.

It is also notable that all of the prevention cases involved the police working in partnership; in the majority, the police collaborated with two or more partners. Those partners were in the main from other public services and the third sector. Collaborations with private sector organizations were the exception, in some notable cases. This points to the necessity of, the inherent requirement for, the police to work in partnership on prevention activity. Huxham (2003) has described this in terms of 'collaborative advantage'; that the benefit of partnership collaboration comes when 'something has to be achieved that could not have been attained by any of the organisations acting alone' (Huxham, 2003, p. 403; Huxham and Vangen, 2005). The cases illustrate the police working with a broad range of other organizations which bring additional and different resources and professional skills to collectively tackle issues of shared concern. It is insufficient, and ineffective, for the police to apply their unique competence in law enforcement to prevention in isolation. We look in more detail at the way in which the police worked in partnership, and the value of those collaborations for the prevention approach they employed, in two specific cases later in the article.

\section{The impacts of police reform and the challenges of prevention practice}

We now explore the impact of the structural and organizational reforms, and the challenges experienced by officers involved in delivering prevention activity. Despite the emphasis on prevention in the policy reforms described above there was a perception among partners that in the early years of Police Scotland there was a reduction in police prevention work in their areas and in the levels of police engagement in the partnerships associated with that activity (Fyfe et al., 2018). This was understood by partners as the result of the police placing organizational focus and priority internally, on the changes required to rationalize the structures and processes from the eight legacy forces.

However, by the time of this research 4 years on from the establishment of the new single force, partners reported a renewed focus by the police on prevention and a reinvigorated commitment to working collaboratively. This is clear in the range of practices highlighted in the case study areas, all of which include partnership working. In our interviews, police managers in particular expressed a strong commitment to prevention and a belief in its benefits: 'it's not about how many things we've detected. It's how many we've reduced.' (A04)

Police interviewees identified a range of other issues in putting prevention into practice. These included the challenge of giving priority to prevention, financial constraints, and the challenge of measuring and attributing the impact of prevention activity. One suggestion was that it was hard to demonstrate or measure the success of prevention, or attribute that to specific police activity. This made it more difficult for police managers to justify giving priority to prevention when setting police budgets. This was particularly challenging in the context of reform where significant financial savings were necessary. This interview extract illustrates the position:

The perennial problem with prevention is that it's most difficult to justify in budgetary terms. Difficult in terms of to be able to demonstrate results, you know?, so it tends to be the one that suffers most when budget pressures arrive, and, to an extent, I'd say that's still the case because it's not something you can measure always very easily ( $\mathrm{H} 02)$.

There was also a suggestion that police officer time could be allocated to prevention activity 
instead of a financial contribution. This was the situation, for example, in the case where the police could only contribute officer time to a road safety initiative (described further below). However, interviewees reported that it was not always possible for officers to invest time in prevention activities due to a lack of staff availability. The redeployment of officers to newly established national squads had been a significant factor in the early part of the reforms and which led to reduced officer numbers in local areas (Fyfe et al., 2018).

Another issue which was highlighted in the interviews was the challenge of understanding and measuring the impact of prevention activities. A few examples were identified of practice being evaluated, such as in case one below, where an external agency had been commissioned to carry out an evaluation. However, on the whole many of the activities were not evaluated and there was an understanding that the police do not have the skills required to carry out evaluations and understand impact. The following quote from a local police partner illustrates the difficulty of distinguishing different prevention activity by partners and attributing what made an impact:

If you prevent a road accident happening, it saves, you know, so many millions'...Yeah, but what actually contributed to that road accident not happening? Was it the [road safety initiative] ...or is it the road alterations ...or was it the police stopping some dangerous driving in that area? ...that creates that really difficult thing to say, "I have done that, and that has prevented that occurrence happening. (G21)

This creates problems for police officers asked by more senior managers to justify the police time or the money invested in prevention activity, and required to demonstrate the specific impact of the police contribution in collaborative partnerships.

\section{The practice of primary and tertiary prevention}

We now take a more detailed look at two specific cases to explore lessons from less conventional prevention practice. The cases are selected from each end of the prevention typology: one example of primary and one of tertiary prevention. In case 1 , we examine an upstream intervention in Area B on road safety with 14-17 year olds, and in case 2, a downstream intervention in Area D to improve the response to individuals in mental health crisis presenting to the police 'out of hour\$he impetus

Case 1: Primary prevention: rural road safety for young people

The initiative was developed in response to concerns about the rates of death and serious injury in 17-25year-old drivers in a predominantly rural area. The aim was to reach young people before they became drivers and to introduce good attitudes towards driving.

The police formed a new partnership with the fire service, ambulance, and two local businesses to develop and deliver a 1-day training course for predriver young people aged between 14 and 17 years. Participants were taken by their schools to a disused airfield, where they took turns receiving 'hands-on' driving instruction in cars provided by a local car dealer, and road safety advice. Additionally, when not driving, the young people were shown a practical demonstration of how emergency services deal with car accidents.

for case 1 arose when other initiatives taking place in area $B$ to try and improve road safety were reviewed and judged as ineffective. After a period of reflection, the police and partners collectively agreed to take a new approach. This marked a deliberate decision to move away from conventional approaches which aimed at information-giving through delivering presentations and showing 
hard-hitting films in schools. Instead, they decided to use an experiential learning approach and to collaborate with new partners. As a result, the police prevention practice changed: they collaborated closely with new private business partners to design and deliver jointly a practical driving experience for young people before they learned to drive. The setting also changed: it was delivered in an outdoor setting, on land owned by one of the business partners. This was a distinct change from the more conventional use of school or college classrooms. The new partnership enabled the use of that setting and also provided crucial additional resources in the form of the cars used for the practical driving experience. In addition, the view expressed in the focus group discussion was that it was the quality and character of the collaboration, and the recognition of a shared aim, that particularly marked the new approach. This is illustrated in the following focus group extract:

I mean it might be an unusual particular activity, but I think the actually working collectively is not a particularly unusual thing. ..It's just they all get it. They get the idea. They get the concept. They know what we're trying to achieve, and we're all on the same page, and it's that interaction.

It created a lot of positive publicity for all of the partners involved: there was interest from other areas to sharing the learning; the initiative was nominated for national awards for innovation and partnership working; and it received national media coverage.Case 2 is the sole example of tertiary prevention identified in the four areas, an

Case 2: Tertiary prevention: mental health community triage

The aim of this initiative in Area B was to provide an improved response to vulnerable adults coming to the attention of police in a state of mental health distress.
The routine response of the police had been to take individuals to, often busy and noisy, accident and emergency departments or police custody. It was recognized that neither setting was good for individuals wellbeing, nor did they provide a suitable environment to deliver a therapeutic response.

Following concerns raised by the police, a review of NHS services for mental health recommended closer working between the mental health crisis team and the local police. A new multi-agency partnership was formed and an NHS mental health nurse was seconded to the police. Working collaboratively, the partnership led to the design of what was described as a new 'care pathway' where police response officers attending an incident of mental health distress could call a mental health nurse and get their advice on how to respond. If necessary, the nurse provided a telephone consultation with the individual in crisis, often while they remained in their own home.

Interviewees reported that the number of vulnerable individuals taken to accident and emergency or held in police custody was greatly reduced. The quality of service provided to the individuals was felt to be much higher than that provided previously. The time spent by police officers on each incident also reduced.

intervention designed to provide a better response to incidents of mental health distress. The focus of the approach was the wellbeing of vulnerable adults experiencing a point of mental health crisis. The police were frequently called to respond to these incidents and it was identified as a demand pressure by senior police managers. It was also recognized that their conventional response-taking individuals to hospital or police custody for their own safetyrisked causing further harm. As a result, the police entered into a new partnership with parts of the NHS with which they had not previously routinely worked: mental health services and the accident and emergency department of the local hospital.

Through the partnership the police were able to access health resources and expertise they did not 
possess. The partners collaborated very closely to design the new way of responding to these incidents, and then to implement them in practice. The new approach meant emergency response officers needed to form new working relationships with mental health nurses, and to recognize, accept and trust the professional assessment made by the nurses when called on to respond to incidents. This required a significant change in culture and practice among police officers, initially built in a pilot phase and then cemented by their positive experience. The result of this new approach was a much more effective approach that better supported the wellbeing of vulnerable adults and prevented them experiencing additional harm.

Both cases illustrate the police making a significant change to an approach they had been routinely employing for some time. They show how in practice collaborative advantage is realized by the police with their partners, with a particular emphasis on common aims, the building of trust, and with leadership focused on the desired outcome (Huxham, 2003; Huxham and Vangen, 2005). Partnership enabled the police to access additional material and human resources and expertise, and created the opportunity to employ new prevention practices in different settings. In each case, there was a sharper focus on, respectively, safety and wellbeing. And in both cases, the new approach made a significant impact on the effectiveness of police intervention.

\section{Discussion and conclusion}

From the analysis set out above, we finish by drawing out a number of specific insights. First, we have demonstrated the value of applying empirically a typology of prevention from public health. We added a refinement to operationalize the typology by breaking the categories down using the three dimensions of preventive focus, practice, and partners. Together, this analytic framework allowed us to differentiate prevention practices and to distinguish patterns of prevention by the police.

Second, our analysis identified police prevention heavily weighted towards secondary approaches and focused predominantly on issues of crime and disorder. But we also found cases of the police applying primary and tertiary prevention, and applying a sharper focus on vulnerability and harm. We do not suggest this demonstrates, at the time of the research, a transformation in police prevention along the lines set out in the public policy reforms described above. Nonetheless, the cases we have examined point to the potential for the police to better meet those policy aims, and more effectively contribute to improved safety and wellbeing, by giving increasing emphasis to upstream and downstream interventions, and to the partnerships that enable them.

Further progress by the police along the lines we describe also requires a recognition of the continuing challenges they face in implementing prevention approaches in practice. Some of the challenges we identified were associated with the specific circumstances present after the creation of the single force, but the others remain. The scope for broader preventive police action we identify will involve difficult choices about the priority given to the financial contribution and officer time required for prevention activity and for investing in partnership collaboration. In making those choices, our findings indicate how prevention work in partnership can be more effective and reduce police demand.

To conclude, what is reasonable and realistic for the police to contribute towards harm prevention and increasing ambitions for public safety and societal wellbeing? An ongoing review of the role of policing in England and Wales identifies this as a key question which reflects contemporary challenges facing the police (The Police Foundation, 2020). The findings set out in this article provide an answer both by illustrating how the police have successfully innovated to make that contribution, and by identifying the potential to go further. We 
draw the following specific implications for policy and practice. Our analytic framework could be used by police forces as a tool to help them make a strategic assessment of current prevention practice. Doing so would enable them to distinguish the pattern of their current prevention practice and identify strategic priorities for enhancing their prevention activity on harm and vulnerability. Police leaders should be clear-sighted that they are not able to deliver on this ambitious prevention agenda alone; and recognize the collaborative advantage that can result from investing the time and money needed to establish and sustain partnerships. They should particularly encourage officers to look beyond traditional partnerships to forge collaborations with organizations with which they have not routinely worked. As our cases exemplify, new partnerships allow the police to draw on resources and expertise they do not possess; and can be a stimulus for necessary innovation in prevention activity. For innovation in prevention to flourish, it needs an organizational culture and practice which actively embraces it. This can be reinforced by police leaders through encouragement and reward for the adoption of new prevention practices that are demonstrably aimed at reducing harm. Systematic approaches to organizational learning are also important; integrating evaluation as part of this innovation, to identify well-evidenced effective practice and to support its wider adoption.

By way of a brief coda, we finish with this reflection. Questions may remain about the value and importance of prevention activity by the police, particularly in a public health context. The experience of the police in the response to the recent global pandemic is a prompt for further consideration of that role. The police have made a significant contribution to explaining and encouraging whole population adherence to preventive action to minimize the harm and spread of the Covid-19 virus ${ }^{2}$.

\section{References}

Bittner, E. (1990). Aspects of Police Work. Boston: Northeastern University Press.

Brantingham, P. J. and Faust, F. L. (1976). 'A Conceptual Model of Crime Prevention.' Crime and Delinquency 22(3): 284-296.

Cairney, P., Russell, S., and St Denny, E. (2016). 'The "Scottish Approach" to Policy and Policymaking: What Issues Are Territorial and What Are Universal?.' Policy \& Politics 44: 333-350.

Commission on the Future Delivery of Public Services. (2011). Report of the Commission on the Future Delivery of Public Services. Scotland: Scottish Government.

Clarke, R. (1980). 'Situational Crime Prevention: Theory and Practice'. British Journal of Criminology 20(2): 136-147.

Cohen, L. E. and Felson, M. (1979). 'Social Change and Crime Rate Trends: A Routine Activity Approach.' American Sociological Review 44(4): 588-608.

Coote, A. (2012). The Wisdom of Prevention: Long-Term Planning, Upstream Investment and Early Action to Prevent Harm. London: New Economics Foundation.

Fyfe, N. R. and Henry, A. (2012). 'Negotiating Divergent Tides of Police Reform within the United Kingdom.' Journal of Police Studies 25: 171-189.

Fyfe, N. R., Terpstra, J., and Tops, P. (2013). Centralizing Forces: Comparative Perspectives on Contemporary Police Reform in Northern and Western Europe. The Hague, The Netherlands: Eleven International Publishing.

Fyfe, N. R., Anderson, S., Bland, N., et al. (2018). 'Experiencing Organisational Change during an Era of Reform: Police Scotland, Narratives of Localism, and Perceptions from the "Frontline".' Policing: A Journal of Policy and Practice. pay052.

Gilling, D. (2019). 'Thinking about Crime Prevention.' Policing: A Journal of Policy and Practice 13(3): 263-270.

Gough, I. (2015). 'The Political Economy of Prevention.' British Journal of Political Science 45(2): 307-327. Vol

${ }^{2}$ In Scotland, police officers applied temporary powers to enforce social distancing measures in line with public health guidance. The operation of the powers followed a strategy which stressed that officers should use engagement, explanation, and encouragement as much as possible and only use enforcement of the regulations as a last resort. Analysis of operational practice showed this guidance was largely followed: overall, enforcement was used in a small minority of the incidents attended by the police, more commonly in the early weeks of lockdown and then decreasing over time (Independent Advisory Group on Police Use of Temporary Powers Related to the Coronavirus Crisis, 2020). Between 27 March and 31 May 2020, 4,328 Fixed Penalty Notices were issued under the regulations (McVie, 2020). 
Henry, A., Malik, A., and Aydin-Aitchison, A. (2019). 'Local Governance in the New Police Scotland: Renegotiating Power, Recognition and Responsiveness.' European Journal of Criminology 16(5): 573-591.

Huxham, C. (2003). 'Theorizing Collaboration Practice.' Public Management Review 5(3): 401-423.

Huxham, C. and Vangen, S. (2005). Managing to Collaborate: The Theory and Practice of Collaborative Advantage. New York: Routledge.

Independent Advisory Group on Police Use of Temporary Powers Related to the Coronavirus Crisis. (2020). Third Interim Report of the Independent Advisory Group on Police Use of Temporary Powers Related to the Coronavirus Crisis. Edinburgh: Scottish Police Authority.

Kautt, P., and Pease, K. (2012). 'The Division of Labour in Crime Prevention: Crime Science, Criminology and Criminal Justice' . The Howard Journal of Criminal Justice 52(1): 39-54.

Malik, A. (2017). Steering from the Centre: The Scottish Police Authority and Police Governance in Scotland. SIPR Research Summary No: 28. Dundee: Scottish Institute for Policing Research.

McVie, S. (2020). Data Report on Police Use of Fixed Penalty Notices under the Coronavirus Regulations in Scotland. Edinburgh: Scottish Police Authority.

New Zealand Police. (2017). Prevention First: National Operating Model 2017. https://www.police.govt. $\mathrm{nz} /$ sites/default/files/publications/prevention-first-2017. pdf.

Police Scotland and Scottish Police Authority. (2017). Policing 2026: Our 10 year strategy for policing in
Scotland. http://www.scotland.police.uk/assets/pdf/ 138327/386688/policing-2026-strategy.pdf.

Rittel, H. W. J., and Webber, M. M. (1973). 'Dilemmas in a General Theory of Planning' . Policy Sciences 4(2): 155-169. 10.1007/BF01405730

SIPR, Scotcen and What Works Scotland. (2016). Police and Fire Reform Evaluation: Year 1 Summary Report. Edinburgh: Scottish Government.

. (2017). Police and Fire Reform Evaluation: Year 2 Summary Report. Edinburgh: Scottish Government.

SIPR, What Works Scotland and Scotcen. (2018). Evaluation of Police and Fire Reform: Year 3 Thematic Case Study-Partnership, Innovation and Prevention. Edinburgh: Scottish Government.

Scottish Government. (2011). Renewing Scotland's Public Services. Edinburgh: Scottish Government.

Seddon, J. (2009). 'Failure Demand - from the Horse's '. Mouth.' Customer Strategy 1(2): 33-34.

The Police Foundation. (2020). Public Safety and Security in the 21st Century. The First Report of the Strategic Review of Policing in England and Wales. London: The Police Foundation.

Tilley, N. and Sidebottom, A. (2017). Handbook of Crime Prevention and Community Safety. New York: Routledge.

van Dijk, J. J. M. and de Waard, J. (1991). 'A Two-Dimensional Typology of Crime Prevention Projects: With a Bibliography'. Criminal Justice Abstracts 483-503. 